\title{
PSICOFISIOLOGIA E TERAPIA DOS AFETOS
}

PSYCHOPHYSIOLOGY AND THERAPY OF AFFECTS

Oswaldo Giacoia JunioR ${ }^{1}$

Departamento de Filosofia IFCH/Unicamp - Brasil

ogiacoia@hotmail.com

RESUMO: O presente trabalho tem como principal objetivo apresentar a psicofisiologia de Nietzsche como terapia dos afetos, filosoficamente articulada como tentativa de transvaloração da metanoia $(\mu \varepsilon \tau \alpha v o \iota \alpha)$ cristã.

PALAVRAS-CHAVE: Fisiologia. Psicologia. Metafísica. Afetos. Ressentimento. Vingança. Metanoia ( $\mu \varepsilon \tau \alpha v o l \alpha)$.

ABSTRACT: The present paper has as main objective to present Nietzsche 's psychophysiology as a therapy of affects, philosophically articulated as an attempt to reverse the meaning of the of Christian metanoia ( $\mu \varepsilon \tau \alpha v o \iota \alpha)$.

KEYWORDS: Physiology. Psychology. Metaphysics. Affects. Resentment. Revenge. Metanoia $(\mu \varepsilon \tau \alpha v o \iota \alpha)$.

De acordo com a hipótese de interpretação que sustento, a Psicofisiologia é um projeto filosófico que atravessa de início ao fim a obra de Friedrich Nietzsche. Paulatinamente, um programa de terapia dos afetos passa a se apresentar como a meta principal da Psicofisiologia, assumindo a forma de uma therapia mentis, capaz de promover uma correção purificadora de nossos modos de sentir, pensar e agir, uma transformação que, por sua vez, constitui o pressuposto para a libertação do espírito. A terapia nietzscheana dos afetos pode ser entendida como um tratamento de cura, cujo objetivo consiste em criar as condições favoráveis para a convalescença e restauração da saúde - mais especificamente, gerar um aumento de força e resistência, de modo algum a completa ausência de enfermidade, o que, no caso ser humano, seria uma tarefa impossível.

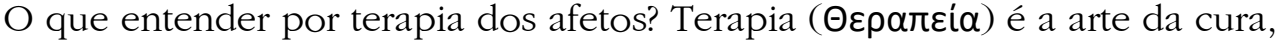
do cuidado e do tratamento - portanto, um termo do vocabulário médico, ligado ao campo semântico da patologia. Affectus é o particípio passado do verbo afficěre

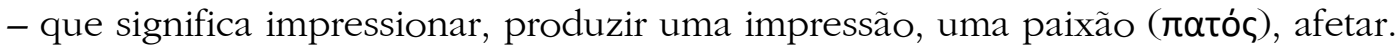

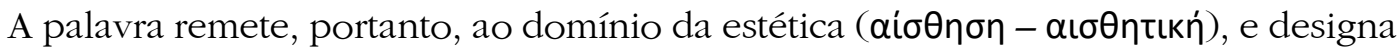

\footnotetext{
${ }^{1}$ Professor Titular do Departamento de Filosofia da Universidade Estadual de Campinas (Unicamp).
} 
sensibilidade, sensação, capacidade de sentir, receber ou sofrer afecções. Nesta última acepção, ela é empregada por Kant na Estética Transcendental da Crítica da Razão Pura. Trata-se da parte do sistema crítico da razão dedicada às formas a priori da sensibilidade, ou da capacidade de afecção.

Nos escritos preparatórios para a publicação de Aurora, Nietzsche concebe um projeto filosófico de crítica do conhecimento e da moral, cuja inspiração é inequivocamente fisiopsicológica; nele, o Nietzsche combina a paixão do conhecimento (Leidenschaft der Erkenntnis) com um projeto de reconduzir os juízos morais a juízos estéticos, e, com isso, à sua base nos afetos. Os juízos de gosto (originariamente atração e repulsão, inclinação e aversão) são as modalidades mais primitivas de juízo.

O belo, o repugnante (das Ekelhafte) etc, é o juízo mais antigo. Tão logo ele sustenta pretensão à verdade absoluta, o juízo estético converte-se em exigência moral. Tão logo neguemos a verdade absoluta, nós temos de abrir mão de toda exigência absoluta, e regressar aos juízos estéticos. Esta é a tarefa - criar uma profusão (Fülle) de estimativas estéticas de valor igualmente legitimadas: cada uma delas, para um indivíduo, o fato último e a medida das coisas. Redução da moral à estética!!! (NIETZSCHE, 1980.2, p. 471).

Correlativamente, o que se deve compreender, então, por afeto? Em geral, o termo designa sentimento, sensação, carga emocional percebida como ligada a uma representação ou vivência. Por exemplo, ser tomado de admiração, espanto, entusiasmo, temor perante algo ou alguém. Há também um particular matiz jurídico digno de destaque, segundo o qual afeto significa ligação, adstrição, vinculação; também ser ou estar gravado por...; como no caso da expressão 'afeto a uma autoridade', a um cargo, status ou a uma condição; ou 'patrimônio ou herança afetados por ônus, uma hipoteca'. Psicologicamente, afeto implica, pois, um quantum de energia psíquica, de natureza emocional, adstrita a uma determinada representação.

Relativamente aos afetos, Nietzsche fala também, por vezes, "simplesmente de 'inclinações e aversões', 'pró ou contra' ou 'favorável o seu contrário'. No fundo, parece que todos os afetos são inclinações ou aversões de alguma espécie. Mas sua gama é extensa. Só em Para a Genealogia da Moral e Para Além de Bem e Mal ele emprega explicitamente o termo afeto para: medo, amor, ódio, esperança, inveja, vingança, luxúria, cobiça, irascibilidade, exuberância, calma, autosatisfação, auto-humilhação, a auto-crucificação, luxúria, ganância, desconfiança, malícia, crueldade, desprezo, desespero, triunfo, sensação de olhar de cima para baixo, sentimento de um olhar superior em relação aos outros, o desejo de justificar-se aos olhos dos outros, exigência de respeito, sentimentos de preguiça, sentimentos de um comando, remorso por más ações. Afetos são, em última instância, maneiras pelas quais nós sentimos" (JANAWAY, 2009, p. 52).

Maneiras de sentir, induzindo ou acompanhando formas de pensar, os afetos brotam no limiar entre o psíquico e o somático, daí sua posição estratégica no pensamento de Nietzsche: a terapia dos afetos demanda o núcleo explosivo e 
subversivo de sua filosofia, a saber, a transvaloração dos valores. Desta cura depende a correção e na modificação dos modos de sentir, pensar e agir, que constitui a base para a libertação do espírito. Como terapia dos afetos, a transvaloração de todos os valores pode ser entendida como uma reversão integral dos modos de sentir e pensar, que encontra seu paralelo na metanoia ( $\mu \varepsilon t \alpha v o ı \alpha)$ cristã.

Este termo deriva de $\mu \varepsilon \tau \alpha$ vocĩv ( $\mu \varepsilon t \alpha \dot{\alpha}$, voũ $)$ ) e designa arrependimento e

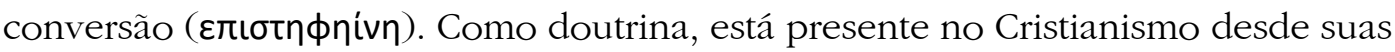
origens remotas, explicitamente nos Evangelhos, em Paulo de Tarso e Tertuliano (160 - 225 d. C.). O arrependimento, enquanto sentimento de pesar ligado ao passado pecaminoso, é o primeiro o passo do crente para a conversão, e a conseqüente renúncia ao pecado em pensamentos, palavras e ações. Esta inflexão produz uma transformação integral de sua pessoa, ou melhor, sua transfiguração ou renascimento espiritual, uma re-significação completa de sua condição existencial anterior.

No hebraico bíblico, a noção de arrependimento é representada por dois verbos: שוב shuv (retornar) and נחם nacham (entristecer, doer, sofrer, pesar), em sentidos que, no Novo Testamento são traduzidos justamente por $\mu \varepsilon t a ́ v o ı$ :

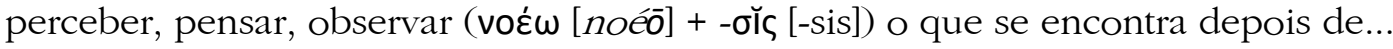
( $\mu \varepsilon \tau \alpha)$, por detrás da mente ou do intelecto. Temos aqui um inesgotável manancial semântico, que envolve o tempo (mudança) e a diferença (velho/novo; mesmo/outro): um perceber, ver e sentir que produz uma modificação interior e exterior, no coração, na mente e no agir; entre os sentidos de epistéphein

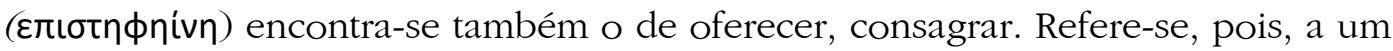
acontecimento no tempo que produz, como uma oferenda, uma alteração substancial: o alívio de um peso que mantém o passado aprisionado a um sentimento negativo de remorso e pesar.

A terapia dos afetos em Nietzsche é uma transvaloração dessa metanoia cristã, que, aos poucos e ao longo do desenvolvimento de sua filosofia, vai assumindo contornos cada vez mais definidos e estáveis, e adquirindo sua plena configuração nos derradeiros escritos do filósofo, em particular em O Anticristo. No entanto, desde muito cedo, encontra-se em ação na obra de Nietzsche uma modalidade de filosofia experimental análoga da metanoia; nela as máximas tensões do pensamento são ainda intensificadas e mobilizadas como recursos estratégicos numa tarefa ética de formação e transformação de Si, que é também cultivo de espíritos livres.

Para tanto, Nietzsche mobiliza suas vivências mais profundas, empreende várias experiências de pensamento, concebe e pratica uma delicada arte de recriação, penosamente amadurecida, nos limites da oposição entre acaso e necessidade, que provê o cenário ideal para a problematização experimental da dialética entre determinismo e liberdade. 


\begin{abstract}
"Mas, se tudo é necessário, como posso eu dispor de minhas ações"? O pensamento e a crença são uma gravidade que, ao lado de todos os outros pesos, exercem pressão sobre ti e mais do que eles. Tu dizes que o alimento, o lugar, o ar, a sociedade te modificam e determinam? Ora, tuas opiniões fazem-no ainda mais, pois elas te determinam a esse alimento, lugar, ar, sociedade. - Se tu incorporas o pensamento dos pensamentos, então ele te transformará. A propósito de tudo, a pergunta: "isto é de tal maneira que eu o quero fazer inumeráveis vezes?" é a maior gravidade (NIETZSCHE, 1980.2, p.496).
\end{abstract}

Em face de textos-chave como este, tematizam a associação o pensamento dos pensamentos (a perspectiva do eterno retorno) e as noções de peso e gravidade, prefigurando a atmosfera afetiva que cerca toda seriedade (Ernst) e seus afetos de acompanhamento - a que Nietzsche dedica um posto central na genealogia dos ideais ascéticos. O peso e a gravidade da circunspecção, ínsitos à seriedade conecta o 'pensamento dos pensamentos' a um sentimento de pesar voltado para o passado e adstrito a ele. Nas malhas desta rede semântica, a seriedade do pensamento, é, então, decodificada como gravidade, e remetida a pesar, a arrependimento e remorso, a afetos aflitivos, opressivos e angustiantes, à procura de resolução. De maneira explícita no texto citado acima, a incorporação do pensamento do eterno retorno produz uma transformação completa do coração e da mente.

Portanto, já no período de composição de Aurora, à vista da alternativa teórica entre determinismo e liberdade, Nietzsche se preocupava com o sentido ético de sua obra: se, como pareciam indicar as ciências da natureza, tudo o que ocorre é resultado de uma necessidade inflexível, então que sentido pode ter qualquer pretensão ética? Já em anotações preparatórias para Aurora e depois transpostas para o interior do livro, Nietzsche reflete intensamente sobre essa questão. Por detrás de nossos pensamentos, conceitos e fundamentações, escreveu ele então, encontram-se sentimentos e afetos, inclinações e aversões; mas, também por detrás dos sentimentos e afetos encontram-se, por sua vez, juízos. Sendo assim, argumentar com sentimentos não implica em demonstrar algo determinante em derradeira instância, pois sentimentos nada têm de originário: por detrás deles encontram-se sempre, segundo Nietzsche, juízos e apreciações, cuja proto-forma são inclinações e aversões incorporadas e herdadas.

Sentimentos e afetos são, pois, netos de juízos - com frequência de falsos juízos, e, em todo caso, não de juízos que nos sejam próprios. Por esta razão, pela qual torna-se imprescindível uma terapia dos afetos, capaz de conduzir a uma reforma do entendimento, com capacidade de retro-ação sobre a esfera emocional dos sentimentos - tudo isso com vistas a uma descoberta de Si, um retorno a um autêntico Si-Mesmo. Na filosofia madura de Nietzsche, este despertamento tomará a forma do tornar-se quem se é, condição na qual figura como subtítulo de Ecce Homo.

Em Ecce Homo, figura com destaque o cuidado minucioso com a dieta alimentar como atitude de respeito por si próprio, e que inclui não apenas a 
escolha dos alimentos, como também a ordem de sua ingestão e a postura corporal, questões que interessam mais a Nietzsche do que as provas da existência de Deus:

Interessa-me uma questão da qual depende mais a "salvação da humanidade" do que qualquer curiosidade de teólogos: a questão da alimentação. Para uso imediato, podemos colocá-la assim: "como você deve alimentar-se para alcançar seu máximo de força, de virtù no estilo da Renascença, de virtude livre de moralina" (NIETZSCHE, 1995, p. 35).

Ao lado disso, encontra-se também a preocupação com o clima, o lugar e a escolha da sociedade, de homens, livros ou paisagens.

Mutatis mutandi trava-se, pois, desde o princípio, de uma terapia dos afetos, levando a uma correção purificadora de nossos modos de sentir, pensar e agir, uma tarefa que, também na obra de maturidade de Nietzsche, coloca-se na base da libertação do espírito. A terapia nietzscheano dos afetos é um tratamento de cura, cujo objetivo consiste em promover a convalescença e restauração da saúde - mais especificamente, gerar um aumento de força e resistência, de modo algum a completa ausência de enfermidade - o que, no caso ser humano, seria uma tarefa impossivel. Esta therapia mentis nietzscheana apoia-se numa economia dos afetos,

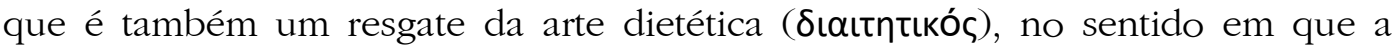
antiga medicina grega compreendia a dietoterapia: um conjunto das prescrições para um modo de vida e alimentação (atividade física, repouso, etc.) aptas a manter o estado de saúde e o bom metabolismo corporal e espiritual, incluindo, pois, aspectos somáticos, intelectuais, ambientais, ecológicos e sociais, como o ilustra um texto que faz parte do corpus hipocrático.

Primeiro é preciso reconhecer a physis de cada pessoa. É preciso reconhecer em que ele consiste desde o começo, reconhecer que elementos (mere) nele [num indivíduo, OGJ.] estão "misturados" [...]. Além disso, é preciso levar em conta as estações do ano, as modificações dos ventos, a situação particular do local, as características do ano. Também o surgir e desaparecer dos astros devem ser conhecidos, para que se entenda como evitar as mudanças e excessos de comida e bebida e ventos e de modo geral (as modificações) de todo o cosmos (tou holou cosmou), de onde se originam as enfermidades das pessoas [...]. Se com base nesse conhecimento, tendo em vista a physis de cada indivíduo, se pudesse descobrir a quantidade adequada (arithmos symmetros) de alimento e esforço físico que não seja demais nem de menos, então se teria encontrado a chave da saúde. (STÜCKELBERGER, 2003, p. 115).

Algumas passagens importantes do livro Ecce Homo poderiam ser lidas como atualizações desses preceitos hipocráticos.

Uma parte fundamental da terapia nietzscheana da mente consiste na desnaturalização dos afetos, especialmente dos afetos fortes. No caso que interessa mais de perto neste trabalho, visados são determinados afetos tônicos, os 
sentimentos negativos e 'pesados', as tendências hostis, como a vingança, o rancor, a aflição inerente ao morsus conscientiae. Exemplar, a este respeito, é o tratamento genealógico dado por Nietzsche à vingança, como modalidade de sentimento e pensamento. Ele ganha destaque na desconstrução por Nietzsche - levada a efeito em Para a Genealogia da Moral - de uma teoria ingênua e 'natural' da vingança que, pelo viés da sinonímia entre Ressentiment e Rache (vingança), pretende elucidar as origens do sentimento de culpa e do conceito de justiça. Nessa esteira de argumentação, o adversário estratégico visado por Nietzsche é Eugen Dühring.

Duas razões principais, certamente entre outras, explicam a necessidade teórica desta polêmica: Em primeiro lugar, a Fisiopsicologia de Nietzsche trabalha com um modelo do psiquismo humano que exige o abandono do esquema de reação baseado no modelo mecânico do arco reflexo, tal como o encontramos na obra de Dühring:

Com a mesma necessidade com a qual a reação resulta da ação mecânica, o ferimento espontâneo e hostil tem por resultado o ressentimento, e com isso o aguilhão da vingança. O impulso (Trieb) para vingar-se do ferimento sofrido é também, manifestamente, um dispositivo da natureza que atua no sentido da auto-conservação. (DÜHRING, 1875, p. 224s).

Como salta aos olhos, Dühring toma como modelo de análise a mecânica racional de Newton, e nela a proporcionalidade entre ação e reação, adaptando para o direito o mecanismo físico e as leis de conservação de energia.

Em seguida, há que se considerar que, pelo menos desde o período de Aurora, Nietzsche elabora uma concepção de justiça (Gerechtigkeit) baseada no conceito de equilibrio (Glechgewicht), que tem, como um importante desdobramento, a necessidade de reconsiderar a teoria sobre a origem da justiça baseada no sentimento de vingança. Portanto, Nietzsche tem de refutar a derivação da ideia de justiça feita por Dühring: "Em nossas reflexões morais", escreve este,

[...] consideramos toda ação originariamente lesiva e hostil como objeto de uma necessária reação. De início, essa reação se manifesta interiormente, num sentimento reativo interior, que denominamos também ressentimento e necessidade de retribuição; ou, com a palavra forte, que designa decisivamente o verdadeiro fundamento natural, podemos denominá-lo justamente vingança. (DÜHRING, 1875, p. 224s).

Com isso, Dürhring naturaliza a vingança, fazendo dela o princípio originário da lei e da justiça, não apenas no âmbito do direito penal, mas também como fator decisivo de equilíbrio social.

Desmistificar este tipo de naturalização ideológica da vingança, para desacoplá-la de uma autêntica derivação genealógica do sentimento e da ideia de justiça constitui tarefa prioritária da therapia mentis de Nietzsche. Para ele, a verdadeira compreensão do ressentimento implica necessidade incontornável de considerar sua causação fisio-psicológica, tarefa para a qual a contribuição dos 
psicólogos franceses constitui, aos olhos genealogista filólogo, uma fonte imprescindível. Com efeito, o substantivo 'Ressentiment' - derivado do verbo ressentir -, é atestado desde o século XVI na literatura francesa, e no século XIX integra o léxico científico da cultura alemã, sendo, portanto, de uso comum entre eruditos.

Verbo e substantivo designam uma espécie particular de sentimento, um "sentir persistente, dotado de intensidade afetiva, gerando efeitos duradouros". Embora em tese o substantivo possa também designar um sentimento neutro quanto ao conteúdo, trata-se sempre de um afeto de efeito prolongado, particularmente forte. São prevalentes os sentimentos e afecções negativas, pois estas impregnam-se de modo mais duradouro e estável do que os conteúdos positivos, como, por exemplo, uma inclinação grata e benevolente, que tende a ser passageira. O acento negativo, inevitavelmente preponderante, já se encontra atestado em Montaigne, que presumivelmente introduziu este conceito na literatura francesa. Montaigne também emprega ressentiment no sentido de um 'sentimento negativo, duradouro e persistente, associado a pensamentos de vingança dele resultantes. Desde então, ressentimento figura como um termo denotative de dor, aflição ou pesar constantes, de uma afecção sempre reflexiva e reativa, associada a pensamentos e afetos vingativos. ${ }^{2}$

Para Nietzsche, por sua vez, o ressentimento é um constructo psíquico elaborado, cuja forma provém de uma ligação que reúne um forte sentimento negativo com um pensamento vingativo dele originado. Por esta razão, o ressentimento não pode ser adequadamente compreendido segundo o modelo da imediata reação motora e mecânica, destinada a afastar um objeto causador de mal-estar. Trata-se antes de um dispositivo de compensação, cuja finalidade consiste em assimilar vivências negativas, experiências 'traumáticas' de sofrimento, que carecem de uma elaboração psíquica que as conduza para vias de descarga, na medida em que representam inevitavelmente moções afetivas, excitações causadoras de perturbação, fontes de desprazer.

Com apoio numa reconstituição da gênese de nossos sentimentos e conceitos, torna-se possível compreender - inclusive no plano das instituições culturais - a razão pela qual já nos primeiros documentos históricos nos quais aparece ligada a uma instituição, a vingança de sangue, esta toma a forma da lei de Talião: um elaborado princípio de retribuição e expiação de crimes. É o caso, por exemplo, dos códigos babilônicos de Hammurabi (2000 a.C.) e no Código de Eschnunna (3000 a. C.). Portanto, a vingança não pode ser compreendida como mera reação automática, imediata, como "um contragolpe defensivo, uma simples medida protetora, um 'movimento reflexo' em resposta a uma súbita lesão ou ameaça, do tipo que ainda executa uma rã sem cabeça, para livrar-se de um ácido corrosivo" (NIETZSCHE, 1998, p. 116). Precisamente este, no entanto, é o modelo de explicação de que se vale Eugen Dühring. Ao contrário de Dühring, Nietzsche interpreta a vingança como um complexo processo psico-físiológico, mediado pela ideia de equivalência, retribuição compensatória meticulosamente calculada, o que

${ }^{2}$ Cf. RICHTER, J. et allii. Historisches Wörterbuch der Philosophie [HWPh]. Verbete Ressentimento, Volume. 8, p. 920-921. 
supõe necessariamente uma referência a um plano representacional de estimativas de valor, compensações, troca, intercâmbio, numa fusão de categorias do direito civil e penal, mesmo incipientes e embrionárias, tal como já aparece nas codificações mencionadas acima.

Para se compreender o essencial nesses processos, é necessário remontar à efetiva causação fisio-psicológica do sentimento de vingança e seus derivados. Para tanto, um adequado meio auxiliar consiste em relacionar o sentimento de vingança à reação defensiva de tipo instintivo, ao 'instinto de vingança'. Não, porém, no sentido de Dühring, já que instinto, não é, para Nietzsche, primeira natureza. Este ponto se esclarece inteiramente se mantemos em vista o que Nietzsche entende, desde muito cedo em sua produção filosófica, pelo termo instinto:

Falo de instinto quando algum juízo (gosto [Geschmack] em seu mais baixo degrau) é incorporado (einverleibt); de modo que ele agora excita espontaneamente a si mesmo, e não precisa mais esperar por estímulos. Ele tem seu crescimento por si, e por conseqüência também seu senso de atividade (Thätigkeits-Sinn) impelindo para fora. Estágio intermediário: o semi-instinto, que só reage a estímulos, e além disso é morto. (NIETZSCHE, 1980.2, no 11 [164], p. 505).

Nietzsche tem em vista, portanto, um campo semântico muito amplo, no interior do qual sua peculiar concepção de instinto - que se estende também ao termo impulso - tanto se aproxima quanto se distancia da acepção etimológica original de instinctus, que remete a instinguĕre, no sentido de incitar, instigar. Lato sensu, instinto designa a inclinação ou disposição de ânimo estável, a índole ou o temperamento, a natureza particular de um indivíduo. Stricto sensu, instintos são impulsos ou tendências que, nos homens e nos animais, provocam ações ou comportamentos consistentes em respostas ou reações substancialmente fixas e imediatas a determinadas excitações. São moções de energia de natureza pulsional - quantidades de força - que acorrem ao psiquismo carregando-o energeticamente, e com isso produzindo uma perturbação em sua economia. Uma carga de excitação que, por sua vez, tem de ser recebida, processada, transformada e distribuída por canais aferentes e deferentes, ou seja, tem de ser descarregada para fazer cessar o desprazer - a perturbação dolorosa - provocada pela perturbação.

A reação constitui o dispositivo de descarga no mundo externo, ou eliminação do quantum de energia acumulada na forma de afeto, e que expressa psiquicamente a pressão de uma necessidade ou carência a ser satisfeita. Pulsões ou instintos são termos dinâmicos, e indicam propensões ou direções para descarga que, independentemente da razão, impelem os indivíduos a realizar certos atos ou a reagir segundo determinados esquemas de comportamento próprios de sua espécie, e eventualmente comuns a outras espécies: p. ex: instinto de conservação; instinto sexual.

Para Nietzsche, a descarga externalizada dos instintos, impulsos e seus afetos de acompanhamento pode ser espontânea e natural, no caso em que ocorra independentemente da necessidade de estímulos externos aos quais reage. Mas 
pode também depender de um elemento desencadeador externo. É o caso do instinto ainda não fixado, não estabilizado, nem completamente incorporado: o semi-instinto. A estabilização ou fixação dos impulsos dá-se, no ser humano, sobretudo por meio de dispositivos, dentre os quais há que contar-se principalmente as instituições. No caso do 'instinto de vingança', o processo de incorporação poderia ser descrito de maneira aparentemente simples: uma vivência negativa é psiquicamente processada como dor, sofrimento ou traumatismo portanto como perturbação do equilíbrio e fonte desprazer ou sofrimento psíquico - que é o resultado da transfiguração da quantidade de excitação num conjunto de representações e afetos, e que pressiona no sentido da descarga.

Este quantum de energia psíquica perturbadora tem de ser elaborada e descarregada para fora do psiquismo, por meio dos canais apropriados, que nele se formam: a vingança, como reação, é justamente um desses canais. Neste estágio, ela não é senão um dispositivo de reação animal: mais precisamente, a descarga da agressividade - da destrutividade animal, tal como aparece na caça, por exemplo - que responde ou reage a um desprazer ou sofrimento causador de perturbação no equilíbrio animal. É por causa disso que Nietzsche denomina a má consciência - a saber, a proto-forma da moralidade - um capítulo da psicologia animal. O sofrimento - que é sentido como dano, porque fonte de desprazer que carece de compensação. Causar sofrimento produz um efeito compensatório, ou seja, infligir sofrimento na causa ou causador do dano é um dispositivo de regulação, que tanto alivia o sofredor quanto restaura o equilíbrio nas relações. Este esquema de reação é criado com base na conexão entre figuras primitivas do direito penal (castigo, punição, que derivam da guerra) e do direito civil mais antigo (as formas embrionárias da obrigação pessoal, troca, dívida, crédito, compra, venda). A lógica paradoxal pode ser descrita da seguinte forma: a dor é instrumentalizada tanto como expediente compensatório eficaz quanto como técnica de memória.

Esta derivação genealógica ganha corpo através do recurso filológico a um deslize semântico facilitado, no idioma alemão, pela equivocidade da palavra Schuld, que reúne os significados de dívida e culpa. Pertence às condições de possibilidade da ideia de obrigação, de dívida e dever, Schuld no sentido econômico-jurídico do termo, a possibilidade de lembrar-se de um empenho, a memória de um ato de vontade, que consiste em assumir uma obrigação, estar em débito: portanto, uma representação que emerge no circuito da troca, da compra e da venda, do débito e do crédito. Para lembra-se de uma dívida e manter-se obrigado a pagá-la, o devedor tem necessidade de conservá-la na memória - o que só é possível se for gravada a fogo num tecido psíquico que é constitutivo da própria memória. Nesse processo, tanto a própria memória como faculdade como a mnemotécnica são produzidas como que simultaneamente, a partir da instrumentalização da dor, numa criação que pressupõe uma inibição - uma temporária colocação em suspenso, como diz Nietzsche - da potência animal do esquecimento, uma poderosa força psíquica de assimilação e metabolismo de vivências. 
A dívida, no sentido econômico-jurídico do termo, aquele sentimento e aquela noção de dever como 'estar em débito', ter dívidas, que nasce no circuito da troca, da compra e da venda, do débito e do crédito, permite o desafogo da má-consciência animal, da crueldade introjetada, da vontade de causar sofrimento, que, nas condições impostas pelo progresso da civilização, não pode mais desafogar-se em sua via natural de descarga, e tem de encontrar canais e meios substitutivos de satisfação. O sentimento de dever - de ter dívidas - e ter de pagar por elas, assim como de ser punido e castigado, caso não o faça é mobilizado para atender a esta necessidade de satisfação substitutiva, e a obrigação acaba por transfigurar-se na mais antiga modalidade da consciência de dever, que remonta, como dispositivo psico-fisiológico, a um capítulo pré-histórico da "psicologia animal" (NIETZSCHE, 1998, p. 129). A dívida em sentido moral, o sentimento de culpa, como dever internalizado e espiritualizado, transformado em consciência do dever, é uma transformação posterior daquela formação originária, de natureza econômico-jurídica.

É neste território que nasce a mais antiga Psicologia - mas também a mais persistente, a mais duradoura, aquela que, em grande parte, é ainda a nossa.

"Como fazer no bicho homem uma memória? Como gravar algo indelével nessa inteligência voltada para o instante, meio obtusa, meio leviana, nessa encarnação do esquecimento?”... Esse antiquíssimo problema, pode-se imaginar' não foi resolvido exatamente com meios e respostas suaves; talvez nada exista de mais terrível e inquietante na pré-história do homem do que a sua mnemotécnica. (NIETZSCHE, 1998, p. 50).

Nietzsche fala aqui da pré-história, dos primórdios (Vorzeit), mas é preciso não perder de vista que tanto para a Genealogia da Moral quanto para sua Fisiopsicologia, a pré-história não é momento cronológico, sepultado no passado, mas uma arché (força originária, uma potência vigente) sempre em atuação em todos as épocas da história humana, o que inclui o presente.

Grava-se algo a fogo, para que fique na memória: apenas o que não cessa de causar dor fica na memória" - eis um axioma da mais antiga (e infelizmente mais duradoura) psicologia da terra. Pode-se mesmo dizer que em toda parte onde, na vida de um homem e de um povo, existem ainda solenidade, gravidade, segredo, cores sombrias, persiste algo do terror com que outrora se prometia, se empenhava a palavra, se jurava: é o passado, o mais distante, duro, profundo passado, que nos alcança e que reflui dentro de nós, quando nos tornamos 'sérios'. Jamais deixou de haver sangue, martírio e sacrifício, quando o homem sentiu a necessidade de criar em si uma memória. (NIETZSCHE, 1998, p. 50s).

A hominização inicia-se, pois, com a criação de uma memória da vontade. Esta memória é o resultado da atividade de uma força atuando violentadoramente contra outra força poderosa: a voragem animal do esquecimento, na tarefa de criação de uma faculdade de lembrança, de um poder lembrar-se, de uma memória ativa, transfiguradora do esquecimento, isto é um paradoxo vivo: um poder-não- 
esquecer. Nietzsche não cogita aqui de nenhuma função deficitária no registro de traços mnêmicos, de uma limitação inevitável dos dispositivos da memória para a fixação de conteúdos; ao contrário: trata-se um ativo poder-não esquecer algum conteúdo inscrito em traços de memória: aqueles que dizem respeito à lembrança da palavra empenhada. Esta é a condição de possibilidade de toda obrigação - a primeira forma propriamente humana de vínculo não mais meramente gregário, mas societário, que se coloca como limiar originário de toda forma de organização social. É dela que deriva também a hominização em sentido próprio, a passagem da physis ao nomos.

Por sua vez, o esquema econômico-jurídico da troca, da compre e venda, débito e crédito, a forma mais arcaica de obligatio entre pessoas e que constitui a matriz da sociabilidade humana, tem sua gênese ligada ao processo psíquico da inibição ou repressão dos impulsos, que é condição indispensável de qualquer modalidade de existência social. Instintos fortes - em particular os destrutivos e hostis - não podem ser descarregados para o exterior, contra os sócios, sob pena de destruição de toda possibilidade de formação de comunidades. A condição vale também para outros tipos de impulsos, mas vale sobremaneira para os agressivos ou destrutivos, que, no entanto, radicam na condição animal do bico-homem. A pressão de tais impulsos, que são urgências, não cessa de exigir satisfação, o que só pode ser realizado por meio de satisfações substitutivas, a saber, pela invenção de novas metas de satisfação. Esta é a gênese da interiorização como sublimação, a 'pré-história da alma':

"Todos os instintos que não se descarregam para fora voltam-se para dentro - isto é o que chamo de interiorização do homem: é assim que no homem cresce o que depois se denomina sua 'alma'." Esta é também a origem da má consciência, com ela foi introduzida no mundo "a maior e mais sinistra doença, da qual até hoje não se curou a humanidade, o sofrimento do homem com o homem, consigo, como resultado de uma violenta separação de seu passado animal". (Nietzsche, 1998, p. 148s). O mistério e o abismo da conditio humana estão envoltos na violência desta separação, situam-se no hiato desta clivagem na qual os procedimentos violentos derivados da guerra - sobretudo os castigos - são interpretados na chave das formas ainda incipientes do débito e do crédito, e instrumentalizados tanto como tecnologia de memória quanto como via de descarga para impulsos hostis - aquela crueldade do semi-animal homem de que trata a segunda dissertação da Genealogia da Moral.

É por esse caminho que a agressividade reprimida encontra sua compensação. Mas a introjeção da descarga, que origina a satisfação substitutiva, deixa sempre uma espécie de saldo negativo, um contingente de insatisfação pulsional, que assume a tonalidade afetiva de sentimento latente de indisposição, uma dor crônica, que exige elaboração psíquica e alívio. Na origem, e portanto em seu estado bruto, a má consciência (como consciência de dever) não é senão o resultado residual da crueldade humana introjetada, que se volta contra o próprio homem, na impossibilidade descarregar-se para o exterior. O rigor dos castigos, as mais cruéis figuras do direito penal, mas também do direito das obrigações, são modalidades de descarga e satisfação e meios de conservação da lembrança de 
promessas e mandamentos, das regras que organizam as comunidades ainda incipientes. A moeda de troca nesse circuito é a crueldade - mais precisamente, a liberação para a descarga de um impulso reprimido, como rara oportunidade de satisfação do afeto mais proibido: o prazer de fazer sofrer, de causar dor como compensação de um dano sofrido, a afirmação do próprio poder sobre um 'inimigo', sobre um 'outro' reduzido à condição de impotência. As possibilidades sempre mais raras de satisfação elevam o valor do meio encontrado: a crueldade é um raro prazer, uma Circe inebriante e inesgotável para a inventividade que deriva da inevitável frustração existencial humana, demasiado humana.

A gênese do ressentimento está ligada a uma modificação decisiva nesse processo. Uma profunda e incurável depressão é inseparável do devir-homem, pois é o resultado incontornável da repressão dos impulsos semi-animais do hominídeo. A depressão é re-significada, isto é, encontra uma perspectiva de sentido, na vontade de causar dor - a saber no desencadeamento da crueldade animal e seus afetos 'selvagens' - um meio de alívio para aquela aflição e pesar semi-conscientes, gerados pelo recalcamento. A dor - enquanto é entendida como vontade de produzir sofrimento como compensação para um mal estar - oferecese como alívio e lenitivo para o sofrimento. Esta é a razão pela qual, segundo Nietzsche, o homem se encontra com frequência cansado de si mesmo, extenuado e esgotado pelo sofrimento. É então que os ideais religioso-ascéticos, ou seja a espiritualização da sede de vingança - da surda revolta - contra esta sofrência incessante, apresentam-se como o nec puls ultra da inventidade. Por meio da interpretação sacerdotal do sofrimento humano crônico, inverte-se a direção do ressentimento, ele visa agora o sofredor em sua existência. A vontade de encontrar um culpado sobre quem descarregar toda sua hostilidade encontra então um alvo socialmente anódino: o próprio sofredor, sua vida, seu existir. É sobre ela interpretada como pecado - que um castigo deve ser aplicado como meio de expiação.

É neste circuito que a lógica paradoxal do ressentimento se revela em seu mecanismo absurdo: a necessidade de entorpecimento da dor por meio da descarga introjetada de afetos hostis, ou seja, anestesiar a dor pela produção intensificada da própria dor. A mesma lógica da mnemotécnica pré-histórica: é necessário bloquear o esquecimento pela dor, para poder ser capaz de lembrar. Mas, para poder novamente lembrar, é necessário continuar a ser capaz de esquecer. A Psicofisiologia do ressentimento é o desvelamento desta contradição, a anamnese da 'patologia' originada pelo bloqueio da força do esquecimento. A disfunção da capacidade de esquecimento ativo produz uma inibição desta potência, um fenômeno que pode ser comparado a uma dispepsia orgânica: tanto o psiquismo quanto o organismo, assim danificados, já não se podem mais dar elaborar, dar conta, processar, assimilar, metabolizar, seus elementos nutrientes; no caso do psiquismo, as vivências, especialmente as negativas e traumáticas.

Esta impotência metabólica produz inevitavelmente sofrimento, que pesa sobre toda a vida psíquica, fazendo-a adoecer. Ressentir significa precisamente isto: tornar a sentir de novo sempre o mesmo, transformar em pesadelo todas as vivências, imantando-a ao peso de uma indisposição visceral, encerrando tudo sob 
a perspectiva única da fraqueza, da impotência, do abatimento que humilha e da ânsia compensatória da vingança. Por isso, do ponto de vista da terapia nietzscheana dos afetos, "estar doente é, isso mesmo, uma forma de ressentimento" (Nietzsche, 1995, p. 30), o doente, nos casos extremos em que sua capacidade de reação ativa é entravada, transforma-se em inesgotável manancial de sentimentos vingativos, acrisolado por uma negatividade que, como Fênix, renasce a cada nova vivência, e que contamina tudo ao seu redor.

Para entorpecer a dor, o organismo (corpo e mente) tem necessidade de descarregar internamente os mais poderosos afetos, como anestésicos eficazes para um sofrimento radicado na incapacidade de esquecer - que, por sua vez, surge como fenômeno patológico ou efeito colateral da criação de uma capacidade ativa de lembrança, a saber, da suspensão parcial da força "digestiva" do esquecimento.

A danificação ou bloqueio da capacidade de genuína reação, esta passa a depender não somente de uma estimulação externa, mas da imaginação como via de descarga interiorizada - a vingança imaginária, apenas in effigie. Esta é a gênese do ressentimento bilioso, venenoso, que constitui a medula afetiva dos ideais ascéticos triunfantes na metafísica e na religião ocidental, bem como da moral socrático-platônico-cristã. A patologia consiste num feixe de contradições: temos aqui um tipo de ressentimento que não tem acesso a uma reação verdadeira (a descarga voltada para o exterior), e que se gratifica com uma descarga internalizada (intrincada com a imaginação, uma vingança imaginária).

E, paradoxalmente, esta via de interiorização da descarga é aberta justamente por uma dimensão de exterioridade: este tipo de ressentido tem necessidade de um 'mundo oposto e exterior', de um 'outro', de um 'fora' de um 'diferente de si', que é o estímulo desencadeante de uma reação que está bloqueada em sua justamente para o exterior, e que tem de voltar-se 'para dentro', para o plano da imaginação. O tipo por excelência deste ressentimento venenoso é o homem do subsolo ou rato de subsolo, genialmente delineado na novela de Dostoiévski.

É indispensável encontrar um culpado para um sofrimento insuportável porque carente de explicação, de justificativa. É imperioso encontrar razões quaisquer razões, pois razões aliviam. A dor da chaga aberta encontra na culpa o seu lenitivo, na vingança a sua compensação, pois, de todo modo, o sofrimento pode afinal ser reconduzido a um motivo, um fundamento, uma razão de ser- e razões aliviam.

Há uma espécie de loucura da vontade, nessa crueldade psíquica, que é simplesmente sem igual: a vontade do homem de sentir-se culpado e desprezível, até ser impossível a expiação, sua vontade de crer-se castigado, sem que o castigo possa jamais equivaler à culpa, sua vontade de infectar e envenenar todo o fundo das coisas com o problema do castigo e da culpa, para de uma vez por todas cortar para si a saída desse labirinto de "idéias fixas", sua vontade de erigir um ideal - o do "santo Deus" - em vista dele ter a certeza tangível de sua total indignidade. (NIETZSCHE, 1998, p. 81).

Em condições de esgotamento, a reação imaginária é uma dissipação e a pior escapatória, porque não constitui uma saída efetiva, uma autêntica reação, 
senão que se esgota num curto circuito paralisante, extinguindo rapidamente quase todas as energias psíquicas ainda restantes. Essa devastação internalizada, as forças nervosas são tragadas pela sede de vingança, que promove justamente o contrário da cura; esta só poderia advir do esquecimento, da força plástica de assimilação, elaboração e metabolismo psíquico. Mas a vingança imaginária, mantendo aceso o circuito da avidez vingativa, o inebriado pelo desejo encontrar culpados e punilos, é apenas um expediente paliativo, que anestesia o sofrimento, mas não cura a memória da ferida, não restaura a potência de assimilação, antes envenena com bílis a vida anímica inteira. Trata-se de um fenômeno similar à adição, uma dependência que necessita de permanente intensificação na dosagem dos entorpecentes.

Em sua avidez, o caminho mais rápido é o da descarga introjetada de afetos vingativos, numa reação incendiária, circunscrita no espaço interno da imaginação, que suga e consome todas as energias num arrebatamento dissipatório, "certamente a forma mais nociva de reação" (NIETZSCHE, 1995, p. 20s), escreve Nietzsche. A analogia entre a evolução da doença, tal como pensada pela medicina helenística e o ressentimento esclarece alguns pontos centrais da Fisiopsicologia nietzscheana. Uma vez alcançado o estágio da agregação inveterada, então "não se sabe nada rechaçar, de nada se desvencilhar, de nada dar conta - tudo fere. A proximidade de homem e coisa molesta, as vivências calam fundo demais, a lembrança é uma ferida supurante" (NIETZSCHE, 1995, p. 20s).

Elucidativa, neste contexto, é a lembrança de Foucault a respeito da proximidade do quadro conceitual entre filosofia e medicina na Grécia clássica e no período helenístico. O conceito de páthos, compreendido como paixão e como doença, adquire especial relevância também para Nietzsche. O desenvolvimento de um páthos (em sentido amplo, como doença) é escalonado em fases, sendo a primeira a euemptosía (proclivitas), o estágio inicial, em que se delineia a configuração da enfermidade; o segundo momento é designado como páthos em sentido estrito (perturbatio: Cícero; affectus: Sêneca): um movimento irracional da alma; seguido pelo estágio do nósema, passagem para a hexis (morbus, em Sêneca), a morbidez crônica, na qual os elementos constitutivos da doença fixamse, cristalizando-se num conjunto definido de disposições incorporadas; este período é seguido, então, pelo o quarto estagio, arróstema (traduzido por Cícero como aegrogatio), no qual o doente transita para um estado de morbidez permanente; e a derradeira fase: a Kakía ouvício (aegrogatio inveterada em Cícero; vitium malum, pestis [corrupção] em Sêneca) culminância da enfermidade, quando o paciente, completamente deformado, fica tolhido no interior do páthos. (FOUCAULT, 2004, p. 101-132).

A diferenciação não se faz, então, entre uma condição enfermiça e uma condição plenamente saudável, mas entre estágios ou fases da enfermidade. Por um lado, aquela do doente incurável e, por outro, aquela do enfermo que pode retornar a si e partir para uma nova saúde, tendo a grave enfermidade como condição. Essa diferença está ligada ao modo como o doente ainda pode lidar com o próprio ressentimento. Minado pela bílis infecciosa da vingança, debilita-se no sofredor o fôlego que ainda restava para a força defensiva, capaz de repelir o que 
prejudica - aquele agressivo instinto de cura e resistência, que é também energia de assimilação produtiva e restauração.

Sequestrada pelo ressentimento, a doença se torna fraqueza num sentido particularmente perigoso: em razão da debilidade, o ressentimento invade e domina a consciência do sofredor, transtornando o metabolismo psicológico que regula a alternância entre percepção, esquecimento e memória das vivências, sobretudo o processo de assimilação dos traços de lembranças negativas. Uma vez minada a força plástica do esquecimento, o sofredor se torna incuravelmente ressentido, porque sua consciência é pervadida pelos traços das lembranças aflitivas, que atraem como ímã a energia dos outros estados psíquicos.

Compreende-se, então, que, sob tais condições, o ressentimento constitui, de acordo com o diagnóstico penetrante de Nietzsche, a doença propriamente dita, a fixação, como disposição permanente, de uma disfunção que bloqueia o processo de assimilação psíquica das vivências. Como Kakía, vitium malum e pestis, o ressentimento corrompe, e não deixa lugar no psíquico para a experiência da grande dor, que liberta o espírito, fazendo-o elevar-se acima de si mesmo, superar a intoxicação pelas lembranças mórbidas, e descortinar novos horizontes de visão e poder. Fixado em sua morbidez crônica, quanto mais sofre, tanto mais o doente anseia por livrar-se de seu fardo, recorrendo ao estratagema da narcose da aflição consciente e latente.

A contaminação pelo ressentimento é, então, uma extravagância dos afetos, o maior dos perigos para o sofredor, uma reação a ser evitada, pois que infecciona ainda mais a chaga. É no círculo desse desespero que a terapia do ressentimento permite discernir seu contraveneno: a desativação da sede de vingança de uma força curativa encontrada na ativação de um poder não-reagir, que não se confunde com a resignação, mas denota uma capacidade de renúncia à dissipação ressentida, o reencontro das derradeiras fibras da capacidade de domínio de si; em outras palavras, o poder resistir ao confisco da doença pelo ressentimento em estado terminal.

Contra isso o doente tem apenas um grande remédio - eu o chamo de fatalismo russo, aquele fatalismo sem revolta, com o qual o soldado russo para quem a campanha torna-se muito dura finalmente deita-se na neve. Absolutamente nada mais em si aceitar, acolher, engolir - não mais reagir absolutamente. [...] A grande sensatez desse fatalismo, que nem sempre é apenas coragem para a morte, mas conservação da vida nas circunstâncias vitais mais perigosas, é a diminuição do metabolismo, seu retardamento, uma espécie de vontade de hibernação. Alguns passos adiante nesta lógica e temos o faquir que durante semanas dorme em um túmulo. [...] Porque nos consumiríamos muito rapidamente se reagíssemos, não reagimos mais: esta é a lógica. (NIETZSCHE, 1995, p. 20s).

Para tornar-se capaz disso, porém, é necessário que, no enfermo, ainda não tenham sido inteiramente extintos aqueles mananciais de forças plásticas e restauradoras que Nietzsche identifica com os instintos curativos de resistência e assimilação ativa. É necessário, sobretudo, que o enfermo não tenha sucumbido 
inteiramente à infecção; a saber, que a sede de vingança ainda não tenha se tornado irresistível, e tomado conta dele. Para aquele fatalismo russo na enfermidade, é necessário que, no doente, ainda se mantenha acesa uma pequena chama de autodomínio, que o torna capaz de voltar a si e convalescer. Se, em certo sentido, a própria doença é ressentimento, precisamente isso é também, e paradoxalmente, "o proibido em si para o doente - seu mal: infelizmente também sua mais natural inclinação" (NIETZSCHE, 1995, p. 20s).

Compreende-se, então, os motivos que levam Nietzsche a escrever em Ecce Homo:

Quem conhece a seriedade com a qual minha filosofia assumiu a luta contra os sentimentos de vingança e perseguição (Rach- und Nachgefühlen), até mesmo no interior da doutrina do 'livre arbítrio' - a luta contra o Cristianismo é apenas um caso particular desta luta compreenderá a razão pela qual eu trago à luz justamente aqui eu comportamento pessoal, minha segurança institiva na praxis. Nos tempos da décadence, eu os proibi a mim mesmo como prejudiciais; tão logo a vida tornou-se de novo rica e orgulhosa e suficiente para tanto, eu os proibi como algo situado abaixo de mim. (NIETZSCHE, 1980.1, p. 273).

Esse é um dos topoi mais fecundos da filosofia de Nietzsche: libertar-se do ressentimento, adquirir poder sobre o espírito de vingança, sobre a compulsão à reação, este é o caminho para o resgate da inocência da existência. Na abolição da culpa, como reconquista da inocência para o devir, culmina a filosofia de Nietzsche:

\begin{abstract}
O vir-a-ser é despojado de sua inocência, quando se faz remontar esse ou aquele modo de ser à vontade, a intenções, a atos de responsabilidade: a doutrina da vontade foi essencialmente inventada com o objetivo da punição, isto é, de querer achar culpado. Toda velha psicologia, a psicologia da vontade, tem seu pressuposto no fato de que seus autores, os sacerdotes à frente das velhas comunidades, quiseram criar para si o direito de impor castigos - ou criar para Deus esse direito... Os homens foram considerados 'livres' para poderem ser julgados, ser punidos - ser culpados. (NIETZSCHE, 2006, p. 45s).
\end{abstract}

A negação desta estratégia ressentida e vingativa de responsabilização é a recuperação da inocência: "apenas assim redimimos o mundo" (Ibid.), escreve Nietzsche.

\title{
REFERÊNCIAS
}

DÜHRING, Eugen. Cursus der Philosophie als streng wissesnschaftlicher Weltanschauung und Lebensgestaltung. Leipzig: L. Hermann's Verlag, 1875. 
FOucault, M. A Hermenêutica do Sujeito. Trad. Salma T. Muchail e Márcio M. Fonseca. São Paulo: Martins Fontes, 2004.

JANAWAY, C. Autonomy, affect, and the Self in Nietzsche's Project of Genealogy. In: GEMES, K. May, S. Nietzsche on Freedom and Autonomy. Oxford: Oxford University Press, 2009.

NIETZSCHE, F. Ecce Hommo. In: Sämtliche Werke. Kritische Studienausgabe (KSA). Ed. G. Colli; M. Montinari. Berlin; New York; München: de Gruyter/DTV. Band 6, 1980.1.

—. Nachgelassene Fragmente. In: KSA, Band 9, 1980. 2.
$\frac{\text { Ecce homo Trad. Paulo César de Souza. São Paulo: Companhia das Letras, }}{1995 .}$

- Genealogia da Moral. Tradução de Paulo César de Souza. São Paulo: Companhia das Letras, 1998.

Crepúsculo dos Ídolos. Tradução de Paulo César de Souza. São Paulo: Companhia das Letras, 2006.

RICHTER, J. et allii. HistorischesWörterbuch der Philosophie [HWP]. Band. 8, S. 920-921.

STÜCKELBERGER, Alfred. Hipócrates e Pensamento Hipocrático. In: ERLER, M. \& GRAeSER, A. (orgs.). Filósofos da Antiguidade. Dos Primórdios ao Período Clássico. Uma Introdução. Coleção História da Filosofia. Trad. Lya Luft. São Leopoldo: Editora Unisinos, 2003. 